\title{
User Evaluation of Media Technology in the Urban Scene of the City
}

\author{
Wijdan Deyaa Abdul Jalil \\ Department of Construction Engineering, University of Technology \\ Wijdan_wijdann@yahoo.com \\ Hadeel Mowaffaq Mahmood \\ Department of Architectural Engineering, University of Technology \\ alabdaa.tanmea@yahoo.com
}

\begin{abstract}
The contemporary development in the field of the digital technology for the media has been witnessed an increasing use in the urban scene of the city. This causes disconnection of the visual references of the place, which are replaced by a simulation of the reality by digital images as an alternative to the physical presence. So, the Availability and spread of the new means of visual communication and information technologies create new symbols of contemporary life, that have different levels of acceptances by users. The problem of research is: "The need to detect the user's evaluation of the use of media technology in the urban scene". The research proposal is: The excessive use of media in urban scene led to visual pollution and the lack of sense of place. For its methodology, the research follows three steps: First, the review of the architectural writings that have agreement or disagreement of the presence of media in the urban scene, to find the scalable items to measure the user's evaluation of the urban scene. Second, the implementation of the Questionnaire, which is made by choosing of five case studies representing various urban scenes in Baghdad city (where the media is used), to adopt the questionnaire form designed, as a means of measuring user's evaluation. The research Sample was 40 persons (not architects) and 70 persons (the architects), who have visited the case study sites several times. Third, by using questionnaire form and excel program, the results are Calculated. The research concluded some negative issues, that should be noticed while using media in the urban scene, to avoid visual pollution and provide the sense of place with the help of the specialists. The ease of recognizing and understanding of the user and the limited use of the media are the most important evaluation factors in user preferences.
\end{abstract}

Key words: Media Technology, Digital Technology, Information Technology, Sense of Place, Visual Pollution.

\section{Introduction}

The contemporary era is witnessing a rapid shift towards the use of media technology in all aspects of life, that has been reflected on the urban scene because of its role for the informational and visual communication. Urban scene witnesses an increasing use of digital surfaces with various shapes, colours, sizes, ...etc. It is either isolated of the buildings, being a part of the building facade, essential part of the design of the building or the landscape of the urban space. The properties of media used in urban scene change the relation between the space and the user. It also controls the evaluation of the user for these media. 
Journal of University of Babylon for Engineering Sciences, Vol. (26), No. (6): 2018.

\section{1-Media Technology:}

It is all the cultural expression that could be available using technology, which provide the ways for the receiving, processing and presenting information at the preferable way. Media is used for advertising, communication, transferring political or social message, ...etc. These messages could be written, images, sounds or a mix of them, which could be processed digitally to produce various outputs [1]. It also could be mixed with the artistic presentation and the properties, the symbolic and the aesthetic elements in art, through a complex intersection between static and moving images, ordinary sounds, noise, music and writings, and depends on the technical possibilities offered by the technology of industrial production of digital technology for expression of various kinds. So, contemporary media are based on four principles: communication, interaction, the ability to connect different media, all of which are controlled by digital programming [2], where everything that is audible, visible or otherwise can be converted to digital information and processed to produce drawings, Static or moving images, writings or other outputs using the computer as a medium for processing.

\section{2- Literature Review:}

The use of media technology in the urban scene has been discussed in many literatures, that differ in their evaluation of the use of media technology, either as a part of the facade of the buildings, or as a component of the landscape. Some of the literatures are the following:

- Jean Baudrillard: He discusses the impact of media on public space, including streets, sculptures, markets and platforms, where media transform buildings into large display facades, replace public space with a giant movement and an interconnected space, that can be described as temporal. He Interprets the effect of media according to Mcluhan's statement, that "Media is the Message". Which means that the influence of the media is not through the content you transmit, but through the patterns associated with the substance of technology and that interacts with the media accordingly, is making it an unreal interaction and a simulation of the truth. He believes that the media represent the central trend of social control, the integration into the consumer society, the important reason for alienation and separation and the reason for the replacement of symbolic rituals with technological rites and replacing physical presence with signs, which must be able to fulfil the role of symbols to some degree [3]. Baudrillard asserts that the proliferation of media has caused modern civilization to dominate the truth by imitating it, replacing the physical world with the nonphysical digital communication and the disconnection with visual references [4].

- Jaschko Susanne: She discussed the change of the traditional scene of the public space as a result of its transformation towards the overloading of optical images in order to promote consumption, which may lead to the Loss of guidance of the society. She also believed in the adoption of the value of sensory influence in the use of media in architecture, not to be over the integration of these media with the building, the context, the function and the construction, or just being as a vector of information content. She also discussed the argument about the cultural value of media entry into urban space as a difficult task, because 
Journal of University of Babylon for Engineering Sciences, Vol. (26), No. (6): 2018.

of its influence on architecture, urban planning and society in general, which requires the consideration of the interconnected changes [5].

- Litta Primasari: Primasari's presentations address the impact of urban screens in the formation of the physical urban space. The dynamic images presented for visual motion in fixed architectural structures have made them part of the components of contemporary urban space, in addition to other physical components. This has led to the emergence of a new space dimension in Contemporary urban space, affecting the interaction between people and their interaction with space. The use of media screens generates what can be called "No Place", where there is no historical trend linking the place with meaning and identity. These spaces are characterized by a lack of ability to provide satisfactory experience, while they contribute to the emphasis on non-historical aesthetics and lack of identity. Walking through these spaces causes the feeling of being a traveler or customer, the loss of personal identity and the sense of independence and individuality due to visual overlapping and photo editing $[6]$.

- Robert Venturi: He deals with the characterization of the architecture at the end of the twentieth century in its tendency to create meanings by representing the quality of the product imposed by the capitalist expansions. He discussed the introduction of trademarks that has played a role in controlling the appearance of cities. He also stressed on the facades as a mirror that reflects their own functions and meanings, independent of the originality of the facades. He describes modernity for its adherence to pure forms with the qualities such as such as: dry, empty, dull and irresponsible and the architecture, for him, turned into a building that was all one decorative element. In contrast to historical sites that send either functional or symbolic messages, cities in modernity have lacked this quality and have been compensated by the media as a means of communicating information to people. Each sign can be understood at three levels: pedestrians, cars and highways. This is where the information, communication provided by the media permeates the space and the architectural form, and the signs become an alternative to architecture in the urban landscape. Then, without these signs, the desert city will become "no place" [7].

- Bernard Tschumi: Tschumi's thoughts are influenced by the digital revolution as a mixture of performance and cinema as a flowing stream of screen projections and people. He describes media in the city as a special event, which is not a steady but constantly changing. So, for him, the city became a dynamic event called the city of the event, which includes unpredictable human interactions. He believes that the "media shock" has caused a constant and steady flow of stunning images. He describes what we observe today in our modern cities as a fragmenting, spatial displacement and separation, that is represented by highways, marketing centers, high buildings and small houses. The image of the contemporary city is a contradict attempt to nostalgia and restores the impossible continuity of the traditional space. It is an urban shock that strengthens and accelerates the urban experience during conflicts and separation from traditional image [8].

- Peter Eisenman: Eisenman's proposals deal with the employment of media in architecture, that unifies the message of the building with the building itself, so his opinion that both 
Journal of University of Babylon for Engineering Sciences, Vol. (26), No. (6): 2018.

architecture and culture connected with the media. He agrees with the idea of transforming the content of architecture into media and its displacement by changing the relationship between form, structure, meaning and symbolism, despite the physical truth of architecture, the meditative conception became the truth itself, through the dramatic change of interaction between man and events in the details of daily life of the user. If the architecture is a direct translation of the truth, it must reflect the employment of media. So, the building today no longer needs to be clear. The traditional concept of the architecture has changed as a reflection of the meaning, philosophy and function in its facades and structure to the idea that the building should not have any meaning at all. Although the building actually has a function, it does not have to appear as it is [9].

The conclusion of the previous literature is:

- Media technology is an important part of contemporary life, which is reflected in all aspects of life, including architecture and urban spaces related to it. Architecture is a translation of reality and thus a reflection of the reality is the dominance of the digital revolution that is represented by the employment of media.

- The proliferation of media in the urban facades is a departure from the visual references of the place and replacing it with a simulation of reality. Digital images are an alternative to the physical presence through the provision of new means of visual and informational communication and the creation of new symbols of contemporary life.

- The changing the concepts and values of the urban space due to the excessive use of visual images and its reflection on the interaction of man-space because of the exposure to the sense of "placelessness", the loss of personal identity and the presence of the new aesthetic preferences associated with the characteristics of media.

\section{3 -Identifying the problem of research and its hypothesis and purpose:}

3-1- The research's problem is: The need to detect the user's evaluation of the use of media technology in the urban scene.

3-2- The research proposal is: The excessive use of media in urban scene led to visual pollution and the lack of sense of place.

3-3- The research's goal is: Determining the priority of media properties in the urban scene, which is evaluated by the user.

3-4- The research follows a methodology with 2 steps: First, finding the scalable items, depending on the above literature review to measure the user's evaluation of the urban scene. Second, the implementation of the Questionnaire, which is made by choosing of five case studies representing various urban scenes in Baghdad city (where the media is used), to adopt the questionnaire form designed, as a means of measuring user's evaluation. 
Journal of University of Babylon for Engineering Sciences, Vol. (26), No. (6): 2018.

\section{4- Media in urban scene:}

\section{4-1- Media types in urban scene:}

There are various types of media technology that are used in urban scenes. LED or LCD screens are very large video screens on the building facade, providing large area surfaces with small dots of resolution and high accuracy, making the facade as a source of effective lighting and image manipulation, and can be installed on different surfaces. LED is an abbreviation for Light-Emitting Diode. It passes the electricity in a direction and prevents it from passing in another direction, while namely LCD screens is an abbreviation for (liquid crystal display). The LED technology is used to enhance the brightness and provide backlighting. The normal LCDs are lit with fluorescent light, which results in poor screen resolution when displaying black and dark colours in general, because the light stays lit all the time to shine dark areas. Other types are used like Bill boards, Plasma screens, Information displays, Holographic screen projections, Dynamic or Intelligent surfaces, ...etc. [10].

\section{4-2- Properties of technology of the media in urban scenes:}

The effect of technology of the media depends on its properties like: its size, colour, brightness, composition, relationships of its component and the building, location, neighbours, ...etc. [6] . Various media technologies are used in different media screens that differs in the resolution of the image, colour, intensity of light emitted and materials used depending on the desired effect and the type of images required, if they are fixed or moving. These screen interfaces are designed and implemented in cooperation between the architect and other related engineering disciplines, where all types of electronic communication technology are tested in the urban facades and converted to the centre of information [11]. The effect of lighting emitted by the media screens, changes the familiar relationship between the viewer and space in dimensions, distances, the absence of physical hardness, the rapid change in the scale and proportions, the identification of edges, mixing and overlap in the space and intensify the mysterious relationship between truth and fantasy, as the latter became part of everyday life [12].

4-3- The relationship between media and the building in urban scene: it could be one of the following:

A- The media are independent of the building: In this case, the urban space is called "eclectic space". It represents the fusion of space components. So that, each structure remains conservative with its original meaning. The relationship between the architecture and the space that contains the digital screen indicates their existence together, where the screen has a separate entity from the building and people will feel the existence of each.

B-The media are compatible with the facade of the building: In this case, the urban space is called the hybrid space, the state in which the screens merge with the building, because they need it as a structure. The architectural space turns into what could be called as "screen space" especially at night [6]. The building's facades are covered with flexible, dynamic images that can be controlled with easy-to-install advertising and provide means to advertise 
Journal of University of Babylon for Engineering Sciences, Vol. (26), No. (6): 2018.

or deliver specific messages and decorate the facades by creating a different pattern [13] (Soliman, 2015, p. 55).

C- The media are an essential part of the structure of the building. The urban space is connected to the building, turn into what could be called as the "Mutation space". The situation in which the building is unable to separate from the media because it is an essential part of its composition. This is reflected in urban space because it will be a basic component In its composition as well [6].

4-4- The content of the Media in urban spaces: Media used in urban facades s is adopted to be multi-purpose content, that combines commercial and technical content, which may contain informative writings, fixed or moving images, videos or manipulation of colours and lights for decorative purposes [5]. In other cases, the effect of the content on the viewer doesn't lie in their content itself as much as the patterns imposed and associated with its essence [3].

\section{4-5- Concepts associated with user evaluation of the technology of media in the urban scene:}

4-5-1- Placelessness: It is defined as the sensation generated in the presence of spaces equipped with advanced technology and characterized by excessive media experience that defines these spaces [6]. Globalization and the information economy have reduced the importance of the sense of place because urban scene has been viewed from an economic perspective. The boundaries between the places and the specificity of each of urban space in the main cities, have been abolished, while a general problem has been generated by accompanying new cities and the expansions of old cities. The growing use of media in the facades of buildings or using them independently, create what is called the "media space", which is associated with changing the model of urban space, the traditional physical scale and the organization of movement, where movement's shape, distribution and speed have been changed. The traditional urban scene and the traditional gradients of urban spaces have been replaced by the accumulation and addition of media [14]. The phenomenon of globalization and the immediate spreading of information have contributed to the melting of cultural diversity, which has reduced the importance of the place [1]. Thus, they create $g$ a challenge of the lack of sense of space caused by the spread of international architecture in addition to the spread of media that can be anywhere. Struppek suggests to solve this dilemma by relating the content of these media to the specificity of the region, in order to achieve a local sense. So, these urban screens may emphasize the privacy of the historic urban area, if properly employed through the presentation of special memories, or if they emphasize on the importance of integrating media screens with the design of building facades. Otherwise, it will simply be an advertising medium, that turns the buildings into an advertising architecture, rather than a media façade [15].

4-5-2- Visual Pollution: It could be defined as the lowest level of visual value due to the trademarks displayed on the facades of buildings in public places. Portella considers the negative consequences caused by the irregular use of media in urban space, which influences on the user's perception of space, because of the uncontrolled supply of media and means of 
advertising. She refers to it as a visual pollution. She insists on the importance of controlling the use of media to be in harmony with not only the suitability of media design, but also, with the characteristics of buildings and the surrounding area and the user's understanding of media in urban space. It depends on Variables of social and urban values like: lifestyle, past experience, career orientation, age, gender, personality, ethnicity and cultural background. She believes that there are general visual preferences for most people, which are independent of the urban context. These visual preferences are important in developing general rules for media control in urban centres of different regions. Struppek also believes that the content of these models, must be in a state of integration with existing urban space components, existing architecture, quality options, location and time to ensure good interaction with space users and avoiding noise and visual pollution [15].

5-4-3- Junk Space: It is a term that coins by Reem Koolhaas for the contemporary urban space, to describe the changes in contemporary urban space in its losing of all previous urban models, that followed a certain pattern of rhythm and gradation. Contemporary urban space is based on accumulation and addition to the urban composition (McQuire, 2009, P.4), where the media causes the emergence of the so-called "Virtual Tectonic" as a reflecting to the relationship between user and architecture [1].

5-4-4- Excessive advertising: The situation in which urban space is crowded with the brighter elements of conflicting advertising screens and signs, all of which are in the service of consumption and the goal is profit and trade. Booster considers it having hostile aspects because it does not provide the ability of the user to respond [4].

5-4-5- Temporary Spaces: It is a term related to urban space, that applied with These digital technology and advanced materials like: smart construction materials, smart lighting, video creation technology, hologram projection technology, ...etc., where it is incorporated into the architectural facades introducing Media screen or Urban scenes. These digital technology and advanced materials contribute to create the sense of temporary and ephemeral urban, because of the rapid change of the content of the display screens [15].

\section{6- Concluding the vocabulary of the theoretical framework:}

A collection of the main and secondary vocabulary has been extracted as a result of the theoretical review, that is mentioned in the text, then classified according to the following:

6-1- The types of the media used: It includes video screens, billboards, information displays, ...etc.

6-2- The characteristics of the media used in urban spaces: It includes the number of written words, the preferences of the written language, the preferences of the basic and secondary colours, the height, the size, the intensity and type of lighting.

6-3-The relationship between the media used and the building: It includes the vocabulary of being an independent relationship, attachment or fundamental. 
Journal of University of Babylon for Engineering Sciences, Vol. (26), No. (6): 2018.

6-4- The level of media content: It includes the vocabulary of advertising, informative and aesthetic content.

6-5-The Concepts associated with user evaluation of the technology of media in urban scene and sense associated with the media used: it includes the vocabulary of the sense of Placelessness, the sense of visual pollution, the sense of junk space, sense of excessive advertising and the sense of temporary spaces.

\section{7-Surveying study:}

7-1- Questioner samples for the users: two main types of user were chosen. First, 40 people "not architect", a random sample, who is chosen for the site. Second, 70 people "the architects", who has been visiting the site several times before at day and night.

7-2- Questioner time: It is selected at different hours of the day to highlight the evolution of the user for using media in urban scene of the city. The survey was conducted during the day and night at the first hour after the sunset.

7-3- The case studies: The case studies were chosen from Baghdad city, for both main two parts Karkh and Rusafa.

7-3-1- The reason to choose the case studies: The sites of the case studies are commercial and provided with dense media technology with various types. They are either open spaces or main intersections to connect a number of major streets in Baghdad city.

\section{7-3-2- The list of the case studies:}

1- Mall of Baghdad in the neighborhood of Harthiya in the side of Karkh, Fig. Nos.1, 1a, 1b and $1 \mathrm{c}$.

2- Mall of Mansour in the side of Karkh, Fig. Nos.2, 2a, 2b and 2c.

3- The Nesoor Square, which is near the "Sijood" Palace in the side of Karkh, Fig. Nos.3, 3a, $3 \mathrm{~b}$ and $3 \mathrm{c}$.

4- The Karrada Street, which is close to the commercial and residential sectors, in the side of Rusafa, Fig. Nos.4, 4a, 4b and 4c.

5- The Hurriya Square in the side of Rusafa, Fig. Nos.5, 5a, 5b and 5c. 
Journal of University of Babylon for Engineering Sciences, Vol. (26), No. (6): 2018.
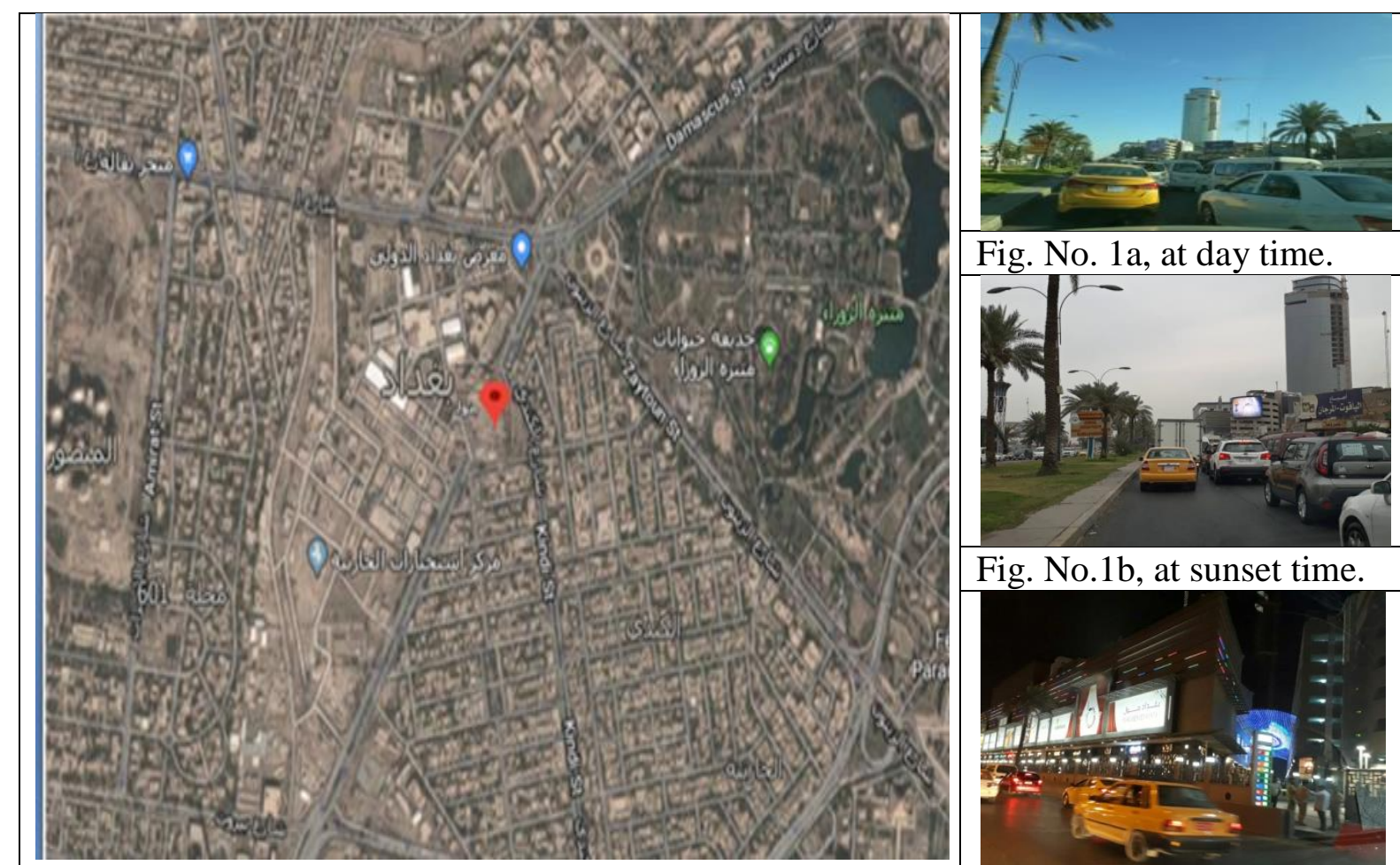

Fig. No. 1a, at day time.

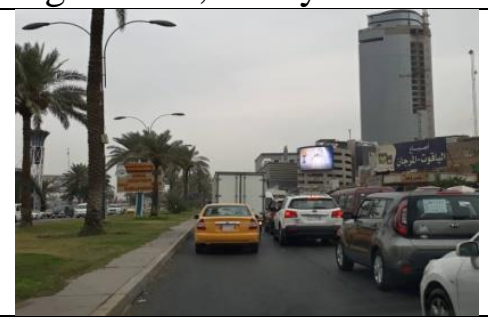

Fig. No.1b, at sunset time.

Fig. No.1, Site

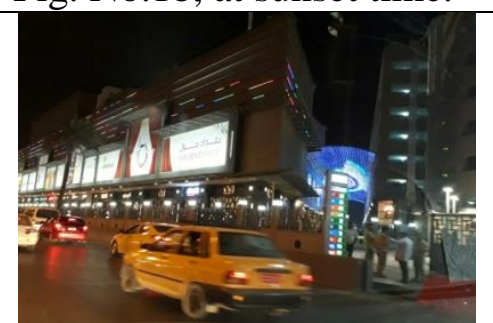

Fig. No. 1c, at night time.

The mall of Baghdad the neighbourhood of Harthiya in the side of Karkh
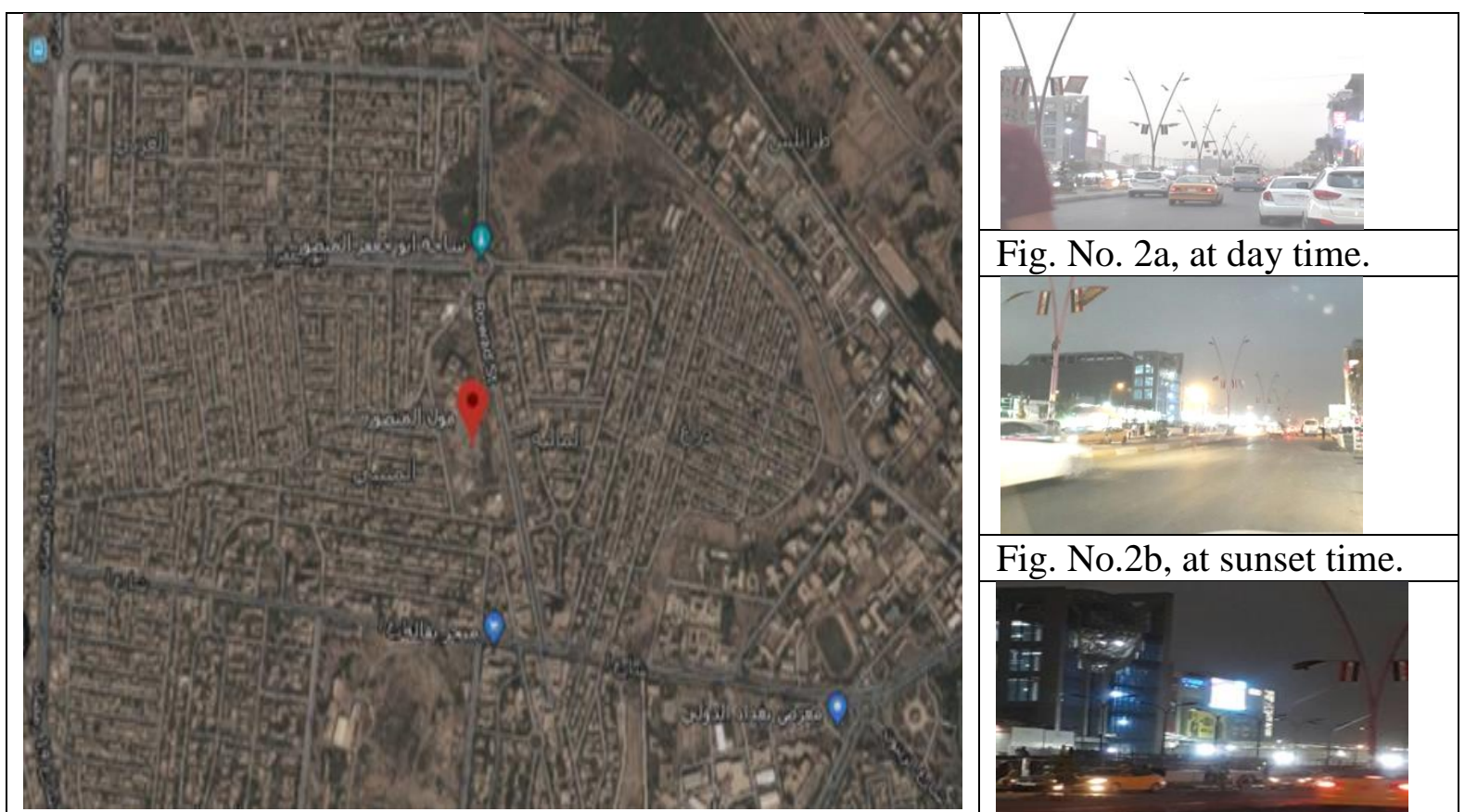

Fig. No. 2a, at day time.

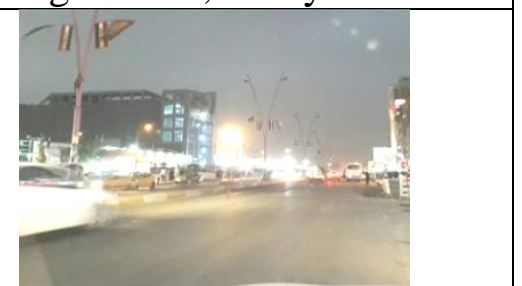

Fig. No.2b, at sunset time.

Fig. No.2, Site

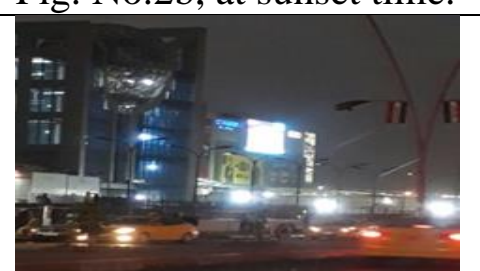

The Mall of Mansour in the side of Karkh

Fig. No. 2c, at night time. 
Journal of University of Babylon for Engineering Sciences, Vol. (26), No. (6): 2018.

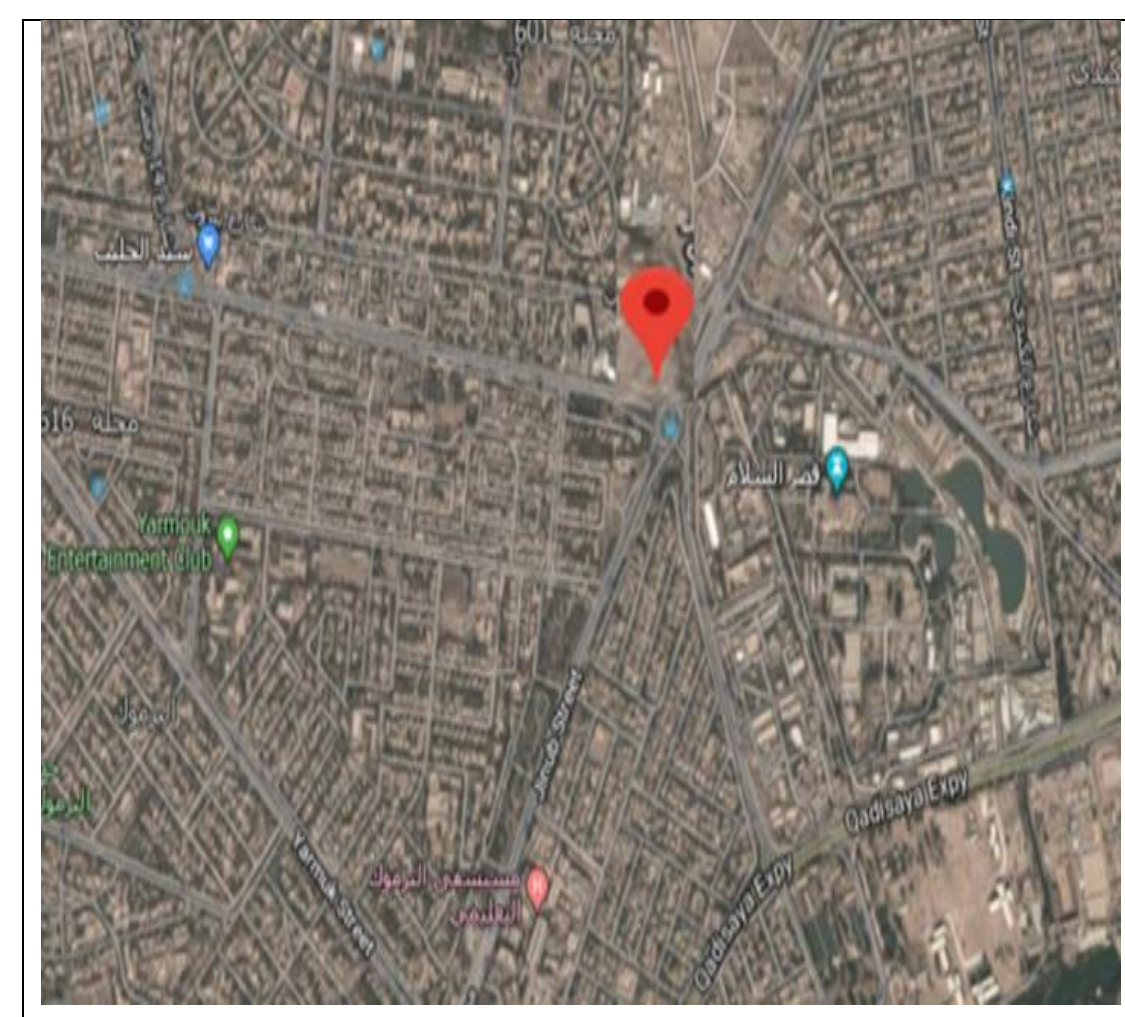

Fig. No.3, Site

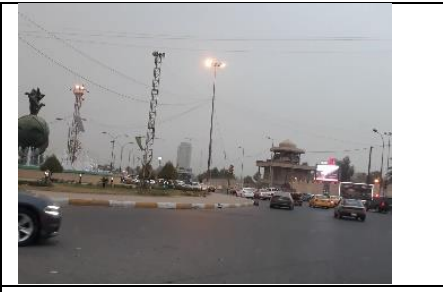

Fig. No. 3a, at day time.

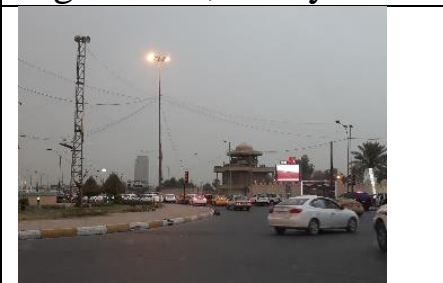

Fig. No.3b, at sunset time.

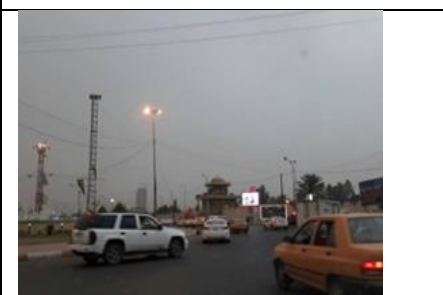

Fig. No. 3c, at night time.

The Nesoor Square, which is near the "Sijood" Palace in the side of Karkh

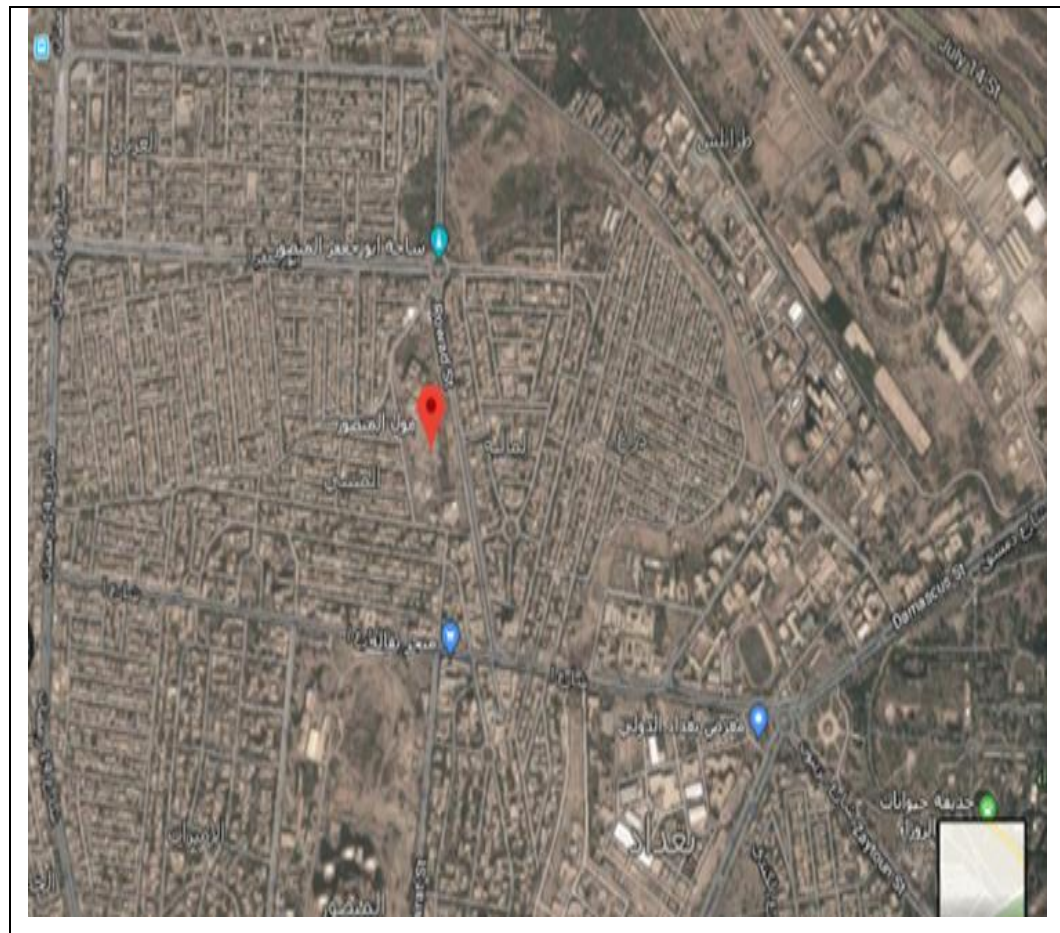

Fig. No.4, Site

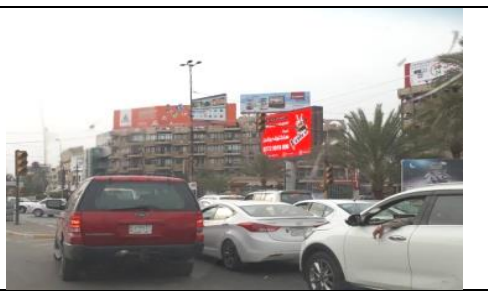

Fig. No. 4a, at day time.

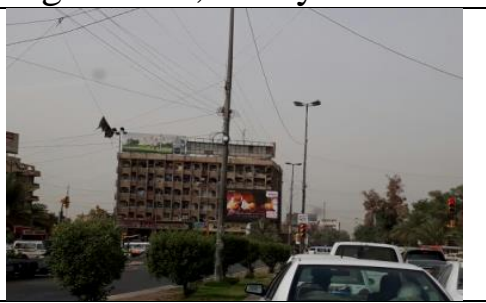

Fig. No.4b, at sunset time.

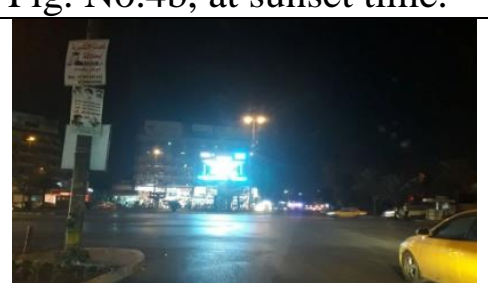

Fig. No. 4c, at night time.

The Karrada Street, in the side of Rusafa. 


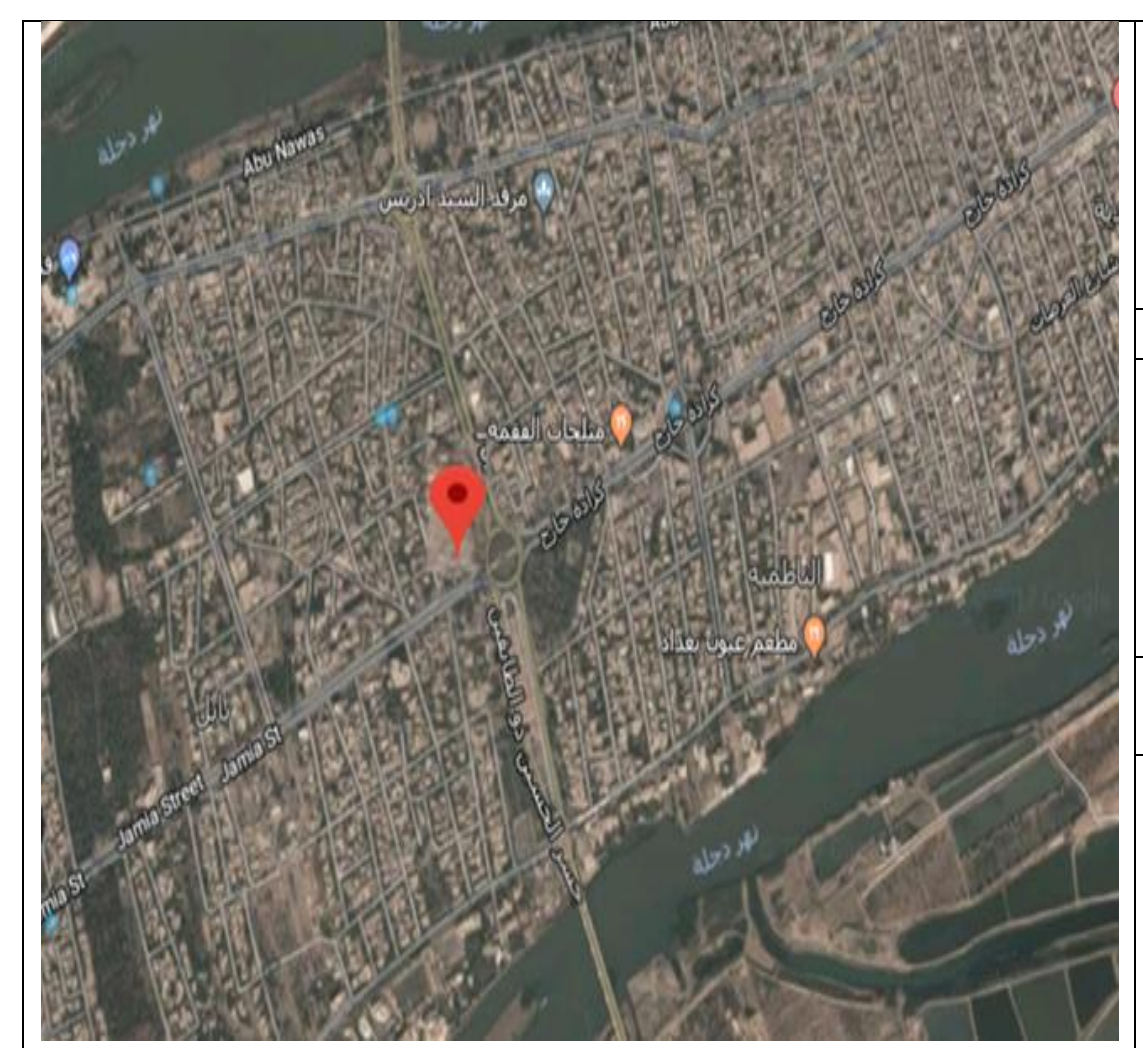

Fig. No.5, Site

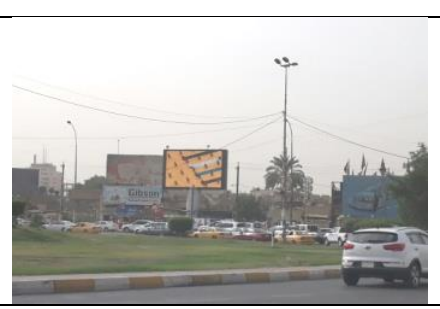

Fig. No. 5a, at day time.

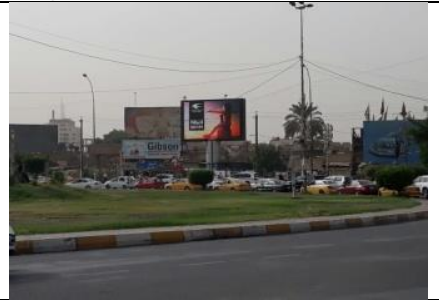

Fig. No.5b, at sunset time.

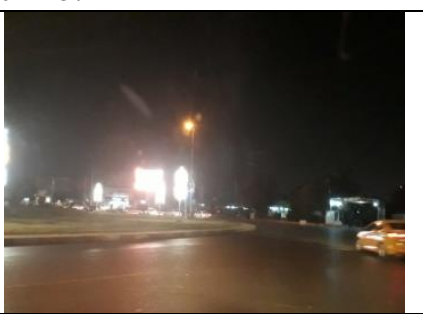

Fig. No. 5c, at night time.

The Hurriya Square in the side of Rusafa

\begin{tabular}{|c|c|c|c|c|c|c|c|c|c|}
\hline \multicolumn{10}{|c|}{ Table No.1 Case studies evaluated by users. } \\
\hline & & & \multicolumn{5}{|c|}{$\begin{array}{l}\text { Nos. of the case studies } \\
\text { No. of is } 70 \text { persons }\end{array}$} & \multirow{2}{*}{$\begin{array}{l}\text { The } \\
\text { avera } \\
\text { ge } \\
\text { value }\end{array}$} & \multirow{2}{*}{$\begin{array}{l}\text { The } \\
\text { percenta } \\
\text { ges } \%\end{array}$} \\
\hline \multirow[t]{2}{*}{ Main vocabulary } & $\begin{array}{l}\text { Second } \\
\text { vocabulary }\end{array}$ & Value & 1 & 2 & 3 & 4 & 5 & & \\
\hline & & & \multicolumn{5}{|c|}{ Total chosen value } & & \\
\hline \multirow{5}{*}{$\begin{array}{l}\text { Purpose to use the } \\
\text { urban space }\end{array}$} & Residence & & 8 & 11 & 3 & 10 & 5 & 7.4 & $10.6 \%$ \\
\hline & Work & & 21 & 23 & 5 & 9 & 10 & 13.6 & $19.4 \%$ \\
\hline & Shopping & & 36 & 28 & 17 & 22 & 12 & 23 & $32.9 \%$ \\
\hline & Visit & & 5 & 8 & 45 & 29 & 43 & 26 & $37.1 \%$ \\
\hline & & & 70 & 70 & 70 & 70 & 70 & 70 & $100 \%$ \\
\hline \multirow{13}{*}{$\begin{array}{l}\text { Evaluation of the } \\
\text { effect of media } \\
\text { types }\end{array}$} & \multirow[t]{4}{*}{ Video screens } & High effect & 31 & 37 & 39 & 42 & 40 & 37.8 & $54 \%$ \\
\hline & & Medium effect & 28 & 25 & 22 & 20 & 26 & 24.2 & $34.6 \%$ \\
\hline & & Low effect & 11 & 8 & 9 & 8 & 4 & 8 & $11.4 \%$ \\
\hline & & & 70 & 70 & 70 & 70 & 70 & 70 & $100 \%$ \\
\hline & \multirow{4}{*}{$\begin{array}{l}\text { Illuminated } \\
\text { advertising } \\
\text { boards }\end{array}$} & High effect & 33 & 40 & 41 & 44 & 45 & 40.6 & $58 \%$ \\
\hline & & Medium effect & 25 & 22 & 20 & 20 & 23 & 22 & 31.4 \\
\hline & & Low effect & 12 & 8 & 9 & 6 & 2 & 7.4 & 10.6 \\
\hline & & & 70 & 70 & 70 & 70 & 70 & 70 & $100 \%$ \\
\hline & \multirow{4}{*}{$\begin{array}{l}\text { Digital } \\
\text { information } \\
\text { screens } \\
\end{array}$} & High effect & 38 & 42 & 41 & 43 & 44 & 41.6 & $59.4 \%$ \\
\hline & & Medium effect & 22 & 20 & 20 & 19 & 17 & 19.6 & $28 \%$ \\
\hline & & Low effect & 10 & 8 & 9 & 8 & 9 & 8.8 & 12.6 \\
\hline & & & 70 & 70 & 70 & 70 & 70 & 70 & $100 \%$ \\
\hline & The numbers & Too many & 41 & 38 & 46 & 47 & 46 & 43.6 & $62.3 \%$ \\
\hline
\end{tabular}


Journal of University of Babylon for Engineering Sciences, Vol. (26), No. (6): 2018.

\begin{tabular}{|c|c|c|c|c|c|c|c|c|c|}
\hline \multirow{24}{*}{$\begin{array}{l}\text { Evaluation of the } \\
\text { properties of the } \\
\text { media used }\end{array}$} & & A lot & 20 & 27 & 21 & 19 & 17 & 20.8 & $29.7 \%$ \\
\hline & & Few & 9 & 5 & 3 & 4 & 7 & 5.6 & $8 \%$ \\
\hline & & & 70 & 70 & 70 & 70 & 70 & 70 & $100 \%$ \\
\hline & \multirow{4}{*}{$\begin{array}{l}\text { Preference of } \\
\text { written } \\
\text { language }\end{array}$} & Arabic & 48 & 47 & 49 & 46 & 49 & 47.8 & $68.3 \%$ \\
\hline & & English & 14 & 13 & 16 & 18 & 12 & 14.6 & $20.8 \%$ \\
\hline & & Both & 8 & 10 & 5 & 6 & 9 & 7.6 & $10.9 \%$ \\
\hline & & & 70 & 70 & 70 & 70 & 70 & 70 & $100 \%$ \\
\hline & \multirow[t]{2}{*}{ The colours } & $\begin{array}{l}\text { Principle } \\
\text { colours }\end{array}$ & 51 & 53 & 55 & 58 & 57 & 54.8 & $78.3 \%$ \\
\hline & & $\begin{array}{l}\text { Secondary } \\
\text { colours }\end{array}$ & 19 & 17 & 15 & 12 & 13 & 15.2 & $21.3 \%$ \\
\hline & & & 70 & 70 & 70 & 70 & 70 & 70 & $100 \%$ \\
\hline & \multirow[t]{3}{*}{ The height } & Appropriate & 52 & 55 & 54 & 57 & 50 & 53.6 & 76.6 \\
\hline & & Inappropriate & 18 & 15 & 16 & 13 & 20 & 16.4 & 23.4 \\
\hline & & & 70 & 70 & 70 & 70 & 70 & 70 & $100 \%$ \\
\hline & \multirow[t]{3}{*}{ The size } & Suitable & 23 & 21 & 20 & 18 & 14 & 19.2 & $27.4 \%$ \\
\hline & & Unsuitable & 47 & 49 & 50 & 52 & 56 & 50.8 & $71.6 \%$ \\
\hline & & & 70 & 70 & 70 & 70 & 70 & 70 & $100 \%$ \\
\hline & \multirow[t]{3}{*}{ Light intensity } & Appropriate & 18 & 20 & 25 & 10 & 14 & 17.4 & $24.9 \%$ \\
\hline & & Inappropriate & 52 & 50 & 45 & 60 & 56 & 52.6 & $75.1 \%$ \\
\hline & & & 70 & 70 & 70 & 70 & 70 & 70 & $100 \%$ \\
\hline & \multirow{5}{*}{$\begin{array}{l}\text { The type of } \\
\text { lighting }\end{array}$} & Continuous & 9 & 8 & 4 & 7 & 10 & 7.6 & $10.9 \%$ \\
\hline & & Flashing & 22 & 30 & 24 & 14 & 22 & 22.4 & $32 \%$ \\
\hline & & Fading & 21 & 20 & 22 & 23 & 12 & 19.6 & $28 \%$ \\
\hline & & Intermittent & 18 & 12 & 20 & 26 & 26 & 20.4 & $29.1 \%$ \\
\hline & & & 70 & 70 & 70 & 70 & 70 & 70 & $100 \%$ \\
\hline \multirow{4}{*}{$\begin{array}{l}\text { Evaluation of the } \\
\text { relationship } \\
\text { between the media } \\
\text { and the building }\end{array}$} & Independent & & 15 & 14 & 44 & 42 & 43 & 31.6 & 45.1 \\
\hline & \begin{tabular}{|l|} 
Consistent \\
\end{tabular} & & 43 & 51 & 23 & 24 & 22 & 32.6 & 46.6 \\
\hline & Basic & & 12 & 5 & 3 & 4 & 5 & 5.8 & 8.3 \\
\hline & & & 70 & 70 & 70 & 70 & 70 & 70 & $100 \%$ \\
\hline \multirow{5}{*}{$\begin{array}{l}\text { Media content } \\
\text { preferences }\end{array}$} & Guidance & & 10 & 9 & 8 & 4 & 6 & 7.4 & 10.6 \\
\hline & Advertising & & 47 & 49 & 46 & 45 & 49 & 47.2 & 67.4 \\
\hline & Aesthetic & & 10 & 4 & 6 & 3 & 4 & 5.4 & 7.7 \\
\hline & Others & & 3 & 8 & 10 & 18 & 11 & 10 & 14.3 \\
\hline & & & 70 & 70 & 70 & 70 & 70 & 70 & $100 \%$ \\
\hline \multirow{6}{*}{$\begin{array}{l}\text { Evaluation of } \\
\text { urban concepts } \\
\text { associated with } \\
\text { the media used }\end{array}$} & $\begin{array}{l}\text { The scene of } \\
\text { the } \\
\text { placelessness }\end{array}$ & & 13 & 9 & 9 & 12 & 10 & 10.6 & 15.2 \\
\hline & $\begin{array}{l}\text { The sense of } \\
\text { visual } \\
\text { pollution }\end{array}$ & & 29 & 27 & 30 & 38 & 36 & 32 & 45.7 \\
\hline & $\begin{array}{l}\text { The sense of } \\
\text { junk space }\end{array}$ & & 5 & 4 & 6 & 7 & 12 & 6.8 & 9.7 \\
\hline & \begin{tabular}{|l|} 
Sense \\
excessive \\
advertising
\end{tabular} & & 13 & 16 & 14 & 9 & 10 & 12.4 & 17.7 \\
\hline & $\begin{array}{l}\text { The sense of } \\
\text { temporary } \\
\text { spaces. }\end{array}$ & & 10 & 14 & 11 & 4 & 2 & 8.2 & 11.7 \\
\hline & & & 70 & 70 & 70 & 70 & 70 & 70 & $100 \%$ \\
\hline \multirow{5}{*}{$\begin{array}{l}\text { The reasons of the } \\
\text { evaluation }\end{array}$} & Guidance & & 9 & 10 & 12 & 16 & 12 & 11.8 & 16.8 \\
\hline & Advertising & & 38 & 39 & 34 & 39 & 35 & 37 & 52.9 \\
\hline & Aesthetic & & 4 & 4 & 6 & 3 & 7 & 4.8 & 6.9 \\
\hline & \begin{tabular}{|l|} 
Others \\
\end{tabular} & & 19 & 17 & 18 & 12 & 16 & 16.4 & 23.4 \\
\hline & & & 70 & 70 & 70 & 70 & 70 & 70 & $100 \%$ \\
\hline
\end{tabular}


Journal of University of Babylon for Engineering Sciences, Vol. (26), No. (6): 2018.

\section{8- Results, discussion and Conclusions:}

8-1-The results: The percentages of the results were completely dependent on the questionnaire for selected sites from Baghdad. The results detailed in (Table No.1)

- The highest percentage of the purpose to use the urban space of the case studies is for the visit, because the chosen case studies are main commercial area.

- The highest percentage of the evaluation of the effect of media types, is for digital information screens.

- The highest percentage of the evaluation of the effect of media's properties is shown as the following:

1. The highest percentage of the user's evaluation of the media's numbers is that: "they are too many".

2. The highest percentage of the user's evaluation of the written language in the media is that: "They must be an Arabic".

3. The highest percentage of the user's evaluation for media's colours is in the principle colours.

4. The highest percentage of the user's evaluation for media's height is that: "They are appropriate".

5. The highest percentage of the user's evaluation for media's size is that: "They are unsuitable".

6. The highest percentage of the user's evaluation for media's light intensity is that: "They are inappropriate".

7. The highest percentage of the user's favourite for the type of lighting is for flashing.

- The highest percentage of the evaluation of the relationship between the media used and the building is that: "It must be Consistent".

- The highest percentage of the evaluation of the effect of media's content, preferences is to be for Advertising.

- The highest percentage of the evaluation of the effect of media's Media content is that: "They generate the sense of visual pollution".

\section{8-2- Discussion:}

- Since the selected studies are commercial, the highest proportion of questionnaire are nonresidents in the region.

- The reasons for the preference of the digital information screens and the guidance purpose of the media are to facilitate the information that are necessary to reach for a specific place and as a guidance through the urban space.

- The users' evaluation of the use of the media is that they are many and inappropriate in the terms of height and size and they cause visual pollution because of the lack of a central coordinating system that allows or does not allow the signing of media in the manner and specification that are required.

- The preference of the users to the language of writing in the media is the Arabic language because it is the mother tongue that could be understood easily. 
Journal of University of Babylon for Engineering Sciences, Vol. (26), No. (6): 2018.

- The questionnaire chose the luminance type flashing and the continent relation between the media and the building because it is easier to recognize.

- Thus, the ease of recognizing and understanding of the user and the limited use of the media are the most important evaluation factors in user preferences.

\section{8-3- Conclusion:}

- Through theoretical studies, the use the technology of media generates urban harmony and cohesion when signed in a service location and benefiting the largest group of society.

- The urban development of cities, the impression of the urban scene and the need for the pace of technological and digital development in recent times, require the use of the technology of the media as one of the methods of the interdependence of the urban landscape of cities and the harmonizing the use of selected sites, which also needs the study of all urban aspects of the city.

- The use of media in Baghdad is made without the help of the specialists. It neglects the people who have the right experience in decision makings and followers of the municipal departments. Otherwise, the bad decisions generate many problems and distorts the urban scene of the city. Then, it results with the bad consequences of the city and its community.

- The placement of the media and their use have a clear and tangible impact in Baghdad streets and squares, where those media generated the growing problems like visual pollution and visual confusion.

- The media preferred by the users to be not only for commercial, but also for the awareness, the guidance and the clarification of multiple things that the community benefits from.

- The impression of the city's civilization and the attention to its environment could be better by the good placing of media, the suitable interdependence and activating the principle of maintaining the skyline of the urban landscape of the city.

\section{8-4-Recommendations:}

- Studying the selected sites for the placing of the media, and specifying their sizes and its other specifications, which operate on an urban sequence and do not distort the urban landscape of the city.

- Highlighting the role of those who are concerned with the municipal and local government departments when signing the media in the sites, because of their positive aspects and determining the approvals by signing them and studying their effects in all respects.

- Using technology and media as a civilized mirror that are developed to fit the urban landscape of the city. 
Journal of University of Babylon for Engineering Sciences, Vol. (26), No. (6): 2018.

\section{Reference}

[1] Maradia S., 2003, Media and Architecture, Ahmedabad, India: Undergraduate Thesis, Centre for Environmental Planning and Technology-CEPT.

[2] Couchot E., 2005, "Media Art: Hybridization and Autonomy," in First International Conference on the Media Arts, Sciences and Technologies held at the Banff Centre, 29oct.

[3] Pawlett W., Jean Baudrillard, 2007: Against Banality, New York: Routledge,Taylor and Francis.

[4] Poster W., Jean Baudrillard, 2007: Selected Writings, 1929-2007, Cambridge, UK.

[5] Jaschko S., 2013, "The Cultural Value of Urban Screens," LPPM ITB, vol. 9 / Dic, pp. $16-25$.

[6] Primasari L. and Lubis B. U., 2013, "Urban Screen and Spatial Dimension," ITB J. Vis. Art \& Des, vol. 4, no. 2, pp. 2-3.

[7] Venturi R., Denise S. B. and Steven I., 1977, Learning from Las Vegas, Revised edition. Cambridge Mass. MIT Press.

[8] Tschumi B., 1994, Event-Cities (Praxis), Cambridge, MA: The MIT Press.

[9] Eisenman P., 1999, "Visions unfolding: Architecture," in The age of electronic media, Free in Spirit in Architecture, L. Galofaro, Ed., Springer, pp. 84-91.

[10] Odilo S., 2007, "Challenges of Media Integrated Architecture: Categorizing the Illusory Real Architecture," in Session 12: Pervasive Computing - eCAADe 25.

[11] Gasparini K., 2010, "Colour and lighting technologies for media facade .IUAV University of Venice, Italy," in First International Conference Proceedings, IUAV University of Venice.

[12] McQuire S., 2008, Performing Public Space, The Media City: Media, Architecture and Urban Space, London: Sage Publication.

[13] Soliman S. I. H., Elrazaz Z. M. and Mohammed S. M., 2015, "The Flexible Facades," Global Built Environment, GBER, vol. 9, no. 3, p. 55.

[14] McQuire S., Martin M. and Niederer S., 2009, Urban Screens Reader, Amsterdam: Raamwerken Printing \& Design, Enkhuizen, Institute of Network Cultures.

[15] Struppek M., 2006, "Urban Screens, The Urbane Potential of Public Screens for Interaction," Intelligent Agent, vol. 6, no. 2, pp. 2-3. 


\section{تقييم المستخدم لتكنولوجيا الوسائط في المشهد الحضري للمدينة وجدان ضياء عبد الجليل \\ قسم هندسة الانثاءات، الجامعة التكنولوجية علية}

Wijdan_wijdann@yahoo.com

هلايل موفق محمود

قسم الهندسة المعدارية، جامعة التكنولوجيا

alabdaa.tanmea@yahoo.com

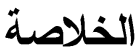

شهدت التطور ات المعاصرة في مجال التكنولوجيا الرقمية الخاصة بالوسائط استخداما متز ايدا في المشهد الحضري

للمدينة. وتسبب ذللك في انقطاع في المراجع البصرية، حيث تم استبدال هذد المراجع بمحاكاة للحقيقة باستخدام الصور

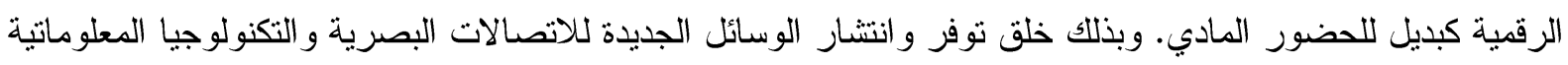

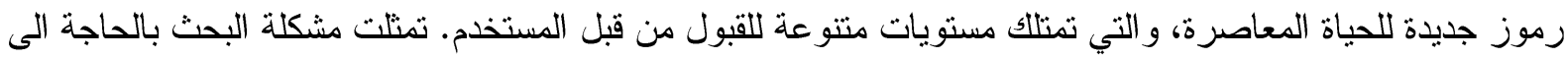
الكثف عن تقييم المستخدم لتكنولوجيا الوسائط في المشهد الحضري. وتحددت مشكلة البحث في الحاجة الى الكثف عن عن فئن تقييم المستخدم لاستخدام تكنولوجيا الوسائط في المشهد الحضري، وبذلك تحددت الفرضية:" يؤدي الاستخدام المفرط

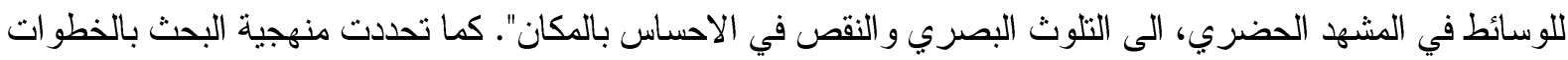

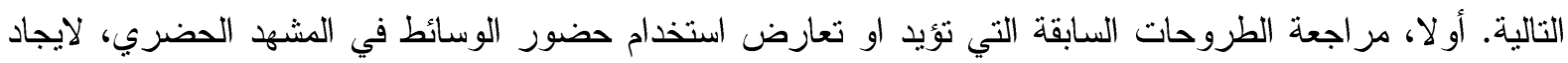
المفردات الضرورية لقياس تقييم المستخدم للمشهد الحضري. ثانيا، اجر اء الاستبيان والذي تم باستخدام خمس حالات دراسية للمشه الحضري في مدينة بغداد (في اماكن تم استخدام الوسائط فيها)، لتطبيق استمارة الاستبيان المعدة. تم

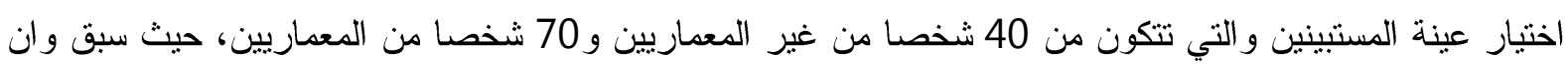

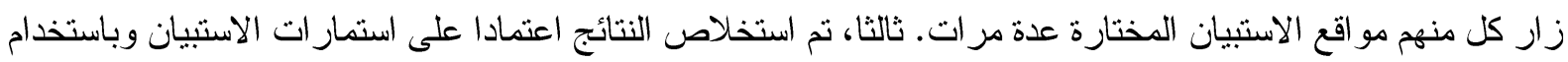
برنامج .Excelحيث توصل البحث الى وجود مجموعة من القضايا السلبية، و التي تم تحديدها لاستخدامية الوسائط في المشهح الحضري، وتم تحديد التوصيات الو اجب اتباعها لتجنب التلوث البصري وتوفير الاحساس بالمكان بمساعدة ذوي الاختصاص، و التي تهدف الى تحقيق اولويات المستخدم في سهولة تمييز المعلومات المعروضة وفهمها وأهمية تحديد كمية الوسائط المستخدمة. الكلمات المفتاحية: تكنولوجيا الوسائط، التكنولوجيا الرقمية، التكنولوجيا المعلوماتية، الاحساس بالمكان، التلوث البصري. 